2. Кориневич А. О. Застосування міжнародного гуманітарного права до збройного конфлікту на території України [Текст] : навч. посіб. / А. О. Кориневич. Одеса : Фенікс, 2015. 78 с.

3. Мерник А. М. Міжнародний досвід правового врегулювання внутрішніх збройних конфліктів / А. М. Мерник // Юридичний науковий електронний журнал № 6/2017. С. 382-385.

4. Про тимчасові заходи на період проведення антитерористичної операції : Закон України від 02 вересня 2014 року № 1669-VII // Відомості Верховної Ради України. 2014. № 44. Ст. 2040.

\title{
DOI https://doi.org/10.30525/978-9934-26-116-9-49
}

\section{DISCLOSURE OF PERSONAL DATA MAINTAINED IN BIOBANKS IN CIVIL AND CRIMINAL PROCEEDINGS: AN EXAMPLE OF NORDIC STATES}

\author{
Lytvynenko A. A. \\ Doctoral student at Baltic International Academy, \\ Department of Legal Sciences \\ Riga, Latvia \\ Doctoral student at Robert Gordon University (School of Law) \\ Aberdeen, Scotland \\ Doctoral candidate at Ivan Franko National University of Lviv, Department \\ of International Law, \\ Lviv, Ukraine
}

The recent judgment of the Latvian Senate (No. SKA-166/2020), upon which the Senate affirmed the legitimacy of a son's request to destroy the blood samples, that belong to his deceased father for the needs of an already ceased criminal investigation, raises concerns on the legitimacy of disclosure or expungement of personal data that are kept in biorepositories - no matter for what reason such data are maintained there [1]. A case relating to expungement of psychiatric records was recently heard at the regional court of Riga [2], which has also brings us to a conclusion that people are concerned about the medical records, maintained in hospitals or forensic examination centers, and are related either to them, or their deceased relatives. Initially, biobanks are designated to be biorepositories maintaining various biological samples for their use in biomedical research, though 
technically any other biorepository, like a forensic examination center, maintaining biological samples, could also be considered being a biobank, though for different purposes. The Latvian Senate has stringently recognized that the data maintained in such biorepositories should be treated as «personal data», as they are collected for the means of processing, which is available by machinery that allows to identify a person by a biological sample - otherwise, these samples could not be considered as personal data [1, para. 11-12]. Rules governing the processing and the legitimate revelation of such data are either general (e.g. data protection law, patient's rights law etc.), or is regulated by special laws and bylaws in some countries. In case of the Latvian Republic, general provisions are applied.

The topic of biobanks is mainly described in the style of positive law explanatory (e.g. an academic discussion on the rules of governing their use), but is fairly known by judicial precedent. One of the most known earlier examples is the foundation of a centralized database of medical records in Iceland, by adopting a special law in 1998, which allowed a private company named «deCODE Genetics» to use the data for the means of genetic research, and people necessitated to notify administrative bodies so as to decline the transmission of their health data into the database [3, p. 300-303]. Later on, a case was brought before the first-instance court of Reykjavik, where the plaintiff, a young woman, demanded to annul an administrative decision to decline her request denying the transfer of her deceased father's medical records to the database. When the case was brought to the Supreme Court, it ruled for plaintiff, admitting that the 1998 act does not ensure her privacy rights sufficiently, and the legal interest of plaintiff in avoiding the transfer of her deceased father's records is comprehensible [4, Section II, IV]. According to the provisions of that law, the consent of the data subject was already presumed, being hardly compatible (if actually compatible), with a basic principle of the informed consent in medical law - both in data privacy and biomedical research issues.

It is true that despite strict statutory regulations on the protection of medical data in the Nordic states, there are diverse exemptions to medical confidentiality. In Finland, a doctor could have no problems with testifying on a deceased patient's health issues in a civil dispute (e.g. concerning the validity of a will, where testator's legal capacity is under question). The Supreme Court of Finland repeatedly found that testifying on the issues possessing medical secrecy is not illegal and would not dishonor the memory of the deceased [5] [6] [7]. In Sweden, apart from other restrictions, the physicians are obliged to provide medical records to inspection boards, which does not contradict the existing legislation, and the inspection boards 
would not acquire property rights in the medical records (for instance, see the Swedish Supreme Court's judgment of 2016 [8, para. 20-26]. The same principle is applied in Norway [9, para. 42-56]. The judicial precedents, created in Norway, are one of the most elaborate in respect with disclosure of data maintained in biobanks in civil and criminal proceedings. Examples, when the disclosure is legitimate may include search of a missing person (presumably deceased abroad) [10]; establishing paternity [11] [12]; requesting the release of tissue examples for a criminal investigation in respect with a minor's death [13]. Such cases were both adjudicated by the Supreme Court and the lower courts.

In a 2018 ruling, the Supreme Court dealt with the issue of whether DNA data from a police register could be admissible in a paternity claim. In 2016, an infant was born to plaintiff who was married to a man named B., and was registered as the child's father. In 2017, plaintiff decided to bring an action to the district court in order to deny B's paternity, asking the court to give an order to obtain information from a police DNA register (B's DNA was taken in connection with a criminal conviction). By that time, B. emigrated from Norway. The trial and appellate courts rejected her claim, and she filed an appeal in cassation claiming that the legislation (The Children's Act, Police Register Act, etc.) and case law would allow such disclosure in a paternity claim. The provisions of two abovesaid acts collided: the first would allow using a DNA sample if the presumed father is dead, or unavailable, while the second stated that information kept in police registers should be used only for the needs of criminal justice. The Court found that the provisions of the Children's Act should be given priority in this case. By a vote of 2-1, the Supreme Court ruled to annul the decisions of the lower courts [11, para 10-33].

As we may notice from the previous judgment, not only legal collisions, but the collisions of interests may occur, and the court has to weigh the circumstances of each case to determine, whom it would give the priority. The Supreme Court's judgment of 2020 is also very illustrative. A 15-months-old boy died in November 2013 under very suspicious circumstances. The forbearers were put on charge, but the forensic experts could not define the precise cause of death, and the case was temporarily suspended. The mother died in 2018, and the father remained the only possible surviving suspect. The biological material was collected from the child twice after his demise: the ones for the needs of the prosecution (destroyed in 2017), and the ones necessitated for a research project «Transformation and redistribution of chemical substances (alcohol, narcotics, drugs) in the body after death», conducted at the Norwegian University of Sciences and Technology, which were stored at the research biobank of the university. The infant's body was cremated [13, para. 3-6]. In 200 
2019, the case was reopened again, and the surviving father was put on charges. Since the only existing samples of the deceased infants were maintained in the said biobank, the police filed a request in order to obtain them to proceed with the criminal case at stake. The University refused, and the prosecution office filed an action to a district court, which rejected it on basis of Art. 27 of the Medical and Health Research Act (2008). The prosecution bod filed an appeal. In a per curiam judgment, the court of appeals held that Art. 27 of the said law could give a rise to request such information only in exceptional cases, where major societal interests are at stake, dismissing the appeal. The prosecution body impugned the decision at the Supreme Court. The court discussed the interpretation of Art. 203-204 (1) and 210 (1) of the Code of Criminal Procedure in respect with obtaining the evidence required for a criminal case, and held, that ordering to obtain any biological samples is in principle admissible. The Art. 27 of the Medical and Health Research Act (2008), said the court, generally did not allow, inter alia, to disclose such medical data for the purposes of prosecution. The last provision of Art. 27 mentioned that additional regulations may be adopted to legitimize such disclosure with weighty interests at stake (public or private), but no such regulations have ever been developed. Then, the Court recalled its position in relation to a provision of the Biobank Act, which had a similar norm (Art. 15 of the Biobank Act). In one of its previous judgments, the Supreme Court ruled, that the tissue samples obtained in connection with the treatment of a person (which later died), could not be given away to the police authorities in the course of a robbery investigation, and underlined that very strong privacy considerations arose from storing medical data in the biobanks. Such approach apparently makes it barely possible (if possible at all) to seize or obtain such biological material by request for the needs of court proceedings. The Court confirmed, that there may be factors prompting for the extradition of the said biological samples, but chose to reject the appeal. On one hand, the case had specific circumstances (the child's demise), the Constitution and the Criminal Procedure Act opted to investigate sudden and unexpected deaths, and it may have soundness in relation to child legal security. On the other hand, the court have a considerable weight to the wording of the law, when it is formulated as an «absolute rule» with all exceptions clearly indicated (which, in fact, were not). Secondly, such a disclosure with no existing clear indication in Art. 27 of the Health Research Act would undermine the overall confidence in medical research and biobanks themselves. Thus, the Supreme Court did not uphold the appeal.

In conclusion, I have to emphasize that the case law in relation to biobanks is still at its dawn, and far not always adequate rules exist in order 
to regulate situations, as described above. Unfortunately, academic scholarship rarely addresses the issue of judicial precedent in relation to biobanks, though cases are emerging one after another, and the courts have either to interpret laws themselves as they choose to do, or decide between conflicting interests separately in each individual case - which could form a robust body of case law in the future. The given abstract displayed the position of the Supreme Court of Norway in two cases - one dealing with a criminal investigation, and another with a paternity claim. The Senate's judgment No. SKA-166/2020 also has many considerations to be taken into account by the legislature in order to develop firm legal regulations in relation to the lawful disclosure and expungement of medical data in the shape of biological samples, stored in biobanks.

\section{References:}

1. A pret. Veselības ministrija, Latvijas Republikas Augstākās tiesas, Senāta Administratīvo lietu departamenta, 2020 gada. 30.septembrī, Lieta Nr. A420260716, SKA-166/2020

2. Administratīva apgabaltiesa, 2020.gada 2. decembri, Lieta Nr. A420209619; Lietas arhīva Nr. AA43-0874-20/10

3. Vilhjalmur Arnason, Bioethics in Iceland Special Section: International Voices 2010, 19 Cambridge Quarterly of Healthcare Ethics 299 (2010)

4. Ragnhildur Guðmundsdóttir gegn íslenska ríkinu, Hæstiréttur Íslands, 27. nóvember 2003, Mál nr. 151/2003 (Supreme Court of Iceland, 27 Nov. 2003, Case no. 151/2003)

5. Supreme Court of Finland, Judgment of 03.10.1983, Case No. R79/1599, KKO:

1983-II-30

6. Supreme Court of Finland, Judgment of 04.05.1984, Case No. S83/286, KKO: 1984-II-60

7. Supreme Court of Finland, Judgment of 2 April 1986, Case no. S85/445, KKO: 1986-II-14

8. Høgsta Domstolen, 2016-11-10, No. Ö2491-15, NJA 2016 p. 922

9. Staten v/Arbeids- og velferdsdirektoratet mot A., Høyesterett, HR2011-2072-A - Rt-2011-1433

10. Borgarting lagmannsrett - Kjennelse LB-2020-182273, 2021-0108

11. A (advokat Elias Christensen) mot B., Høyesterett, HR-2018-2241U, 2018-11-23

12. Høyesterett, HR-2013-868-A - Rt-2013-565 (2013-04-24)

13. Høyesterett, HR-2020-1776-A, 2020-09-14 